\title{
Unprotected In an Islamic Country; Experiences of Childhood Sexual Abuse among Pakistani Women
}

\author{
Anam Shahid $^{1 *}$, Naumana Amjad ${ }^{2}$
}

\section{ABSTRACT}

This study qualitatively explored the experiences of childhood sexual abuse in females. Semi structured interviews with open ended questions were used to obtain in-depth information about various aspects of this experience, ; perpetrator characteristics, type and frequency of abuse, victim's response/reaction, reporting to family or other adults, treatment seeking treatment and perceived effects on mental and physical health. The participants were approached through snow ball sampling. 5 females of different backgrounds and ages who gave consent to share personal information were interviewed. Their verbatim were transcribed and content analyzed. The results of the interviews after content analyzed were that their current age, ages at time of abuse, reporting experiences, relationship with abuser, psychological reactions and counseling sought of or not. To lend support to findings of first study, as a next step, three anonymous stories were selected from the internet and content analyzed. The findings of the study revealed that incident of abuse at home have higher frequency then outside. Three out of five participants were abused by their close relatives, 2 were abused by family friends. Most common form was kissing, touching body parts and showing pornography. The reaction of the family mostly was not supportive. The emotional effects were: sad mood and feeling of unhappy and isolation, worthless and crying episodes. Physical effects ere palpitation, trembling and increasing heart beat immediately after abuse. Some victims of sexual abuse felt sexual repulsion and have difficulty accepting closeness to men. 3 out of 5 participants sought counseling but 1 of 3 participants took counseling after very long time. Two women reported taking sleeping pills for the quality of sleep. So, collectively, from interviews and stories, it was found that the impact of sexual abuse remains same across cultures.

Keywords: Experiences, Childhood Sexual Abuse, Stories, Females, Trauma

Sexual Abuse is an act committed by any personto get sexual gratification and satisfaction by use of force from another person against his or her. It happens against children, adults and

\footnotetext{
${ }^{1}$ Institute of Applied Psychology, University of the Punjab, Lahore, Pakistan

${ }^{2}$ Institute of Applied Psychology, University of the Punjab, Lahore, Pakistan

*Responding Author

(C) 2016 A Shahid, N Amjad; licensee IJIP. This is an Open Access Research distributed under the terms of the Creative Commons Attribution License (http://creativecommons.org/licenses/by/2.0), which permits unrestricted use, distribution, and reproduction in any Medium, provided the original work is properly cited.
} 
members of both genders. Sexual abuse can result in long term negative consequences both physical and psychological problems such as depression, low self-esteem, social withdrawal and anxiety (Linder \& Grashow, 2013). The painful consequences are more severe for children who are vulnerable due to their developmental phases. Sadly there are few societies free of this appaling and shocking crime against humanity. Much research has focused on effects on victims, however there are some unexplored aspects such as victim's reactions, family's reaction and descriptions of incidents that can help create better awareness and aid in planning of counseling and protection policies in our society. Therefore this study examined first-hand information from adult women who had experienced childhood sexual abuse.

Many people believe that childhood sexual abuse is carried out only by authority figures but in reality children are abused by loved ones, family member's family friends and with those who are supposed to take care of them and protect them (Kempe, 1978).

Previous studies show that strangers as well as family members are involved in sexual abuse of children. This suggests that children of all ages and both genders are at risk within families and in larger community. The crime includes several distinct types of mistreatment. Any kind of sexual act to an immature child is damaging because it ruins child'strust violating his/her human dignity. It is a form of exploitation. (Fraser, 1981). The involvement of dependent and developmentally young children and adolescents in sexual behavior they do not truly understand and hence are unable to give consent or derive pleasure from thus becomes doubly damaging. (Kempe, 1978).

Two points of view about victims are mainly the sexually acting theory and passive-victim theory. The sexually acting view suggests that some children act in way that encourages adults to approach them sexually. These children have poor relationship with their parents and are needy in other ways tend to obtain attention and affection from an adult by arousing adult sexual impulses (Burton, 1968). The second theory postulates that many children are victimized by failing to take care of themselves by the means of self-protective actions. They do not take action to step the molestation and are believed to be disturbed and passive, all of which make them vulnerable to become victim (Defrancis, 1969).

A review of the research on victims of sexual abuse tells us that sexually abused children have more symptoms than the non-abused children, but have less symptoms than those who are clinically referred in treatment (Kendall \&Williams, 1993).

The most frequent symptoms of abused children are fears, posttraumatic stress disorder (PTSD), behavioral problems and low self-esteem (Kendall \&Williams, 1993). 
One symptom cannot characterize the whole population and there is no pattern of symptoms that can define a sexually abused child syndrome. Depression, poor performance at school, distraction and decrease in retention and learning ability is also reported (Kendall \&Williams, 1993).

Among adolescents other symptoms such as anxiety, nightmares, PTSD, internalizing and externalizing behaviors are also prominent while withdrawal, suicidal attempts, isolation, selfinjurious behaviors, illegal acts, running away and substance abuse is not uncommon. Longitudinal studies indicate that the symptoms tend to become less sever with the passage of time (Kendall \&Williams, 1993).

A study in Pakistan on adult sample of 248 university students has shown that symptomsof anxiety, depression, OCD, phobia, somatization, hostility, interpersonal sensitivity, paranoid ideation and psychotic features were significantly more as compared to non-abused peers (Ali, 2005). Similar findings have been reported in another study on coping among female victims of sexual abuse (Ahmad, 2010). The females reported symptoms of depression and helplessness and mostly used emotion focused coping that actually is not an effective way of seeking help (Ahmad, 2010).

Jehu, Gazan and Klassen (1985) found that 82\% of survivors blame themselves for the abuse. Trai and Wagar (1978) have also reported a high incidence of guilt among the survivors and suggest that feelings of guilt are universal among women. The impact of sexual abuse can range from no audible effects to very severe ones. Usually, children who experience the most serious kind of abuse, e.g. abuse involving family members and high degrees of physical force report more behavior problems ranging from separation anxiety to posttraumatic stress disorder. However, children who are the sufferers of sexual abuse are also frequently exposed to a variety of other stressors and difficult conditions in their lives. The sexual abuse and its consequences may be only part of the child's negative experiences and succeeding behaviors. Therefore, correctly diagnosing abuse is often complex.. For all of these reasons, when abuse is assumed, properly trained health professional should be consulted (American Psychological Association, 2012).

Along with reporting and diagnosing of abuse, the attitudes of family and public are also important dimension. It is these people who can report and act upon a child's complaint and in the first place make the child aware of possibility of abuse and train him or her in safety and actions for reporting. This is usually absent. A research was conducted to examine attitudes of the general public living in a rural community about child sexual victimization through a population based survey. In a representative sample of the population of rural Klamath country in Oregon. Interviews were conducted in shopping malls, educational facilities, and locations for state and country services and child and parent centers. This study found that the people had 
significant deficits in their perceptions about child sexual abuse such as they are bad child (Shackel, 2008). In view of the above, it is imperative that families, policy makers, educators and social scientist join their efforts to influence not only public opinion but also raise effective protection practices against childhood sexual abuse. The purpose of the present study is to explore the childhood sexual experiences in females focusing on specific points that may aid in designing information manuals for families. A number of studies have examined the effects on victims and some have explored perpetrators. However, useful first-hand information is needed that can be utilized to make action guidelines for victims and families. Pakistan is an Islamic country, yet effective legal and police reporting procedures, arrests and follow up by counseling needs to be devised. Findings of previous studies revealed that sexually abused children undergo severe and often long term psychological problems. They require mental health support and special care in this regard, care givers especially parents, can play their role by responding to complaint of child, being observant and seeking and providing psychological and legal support to victim. We need to know the situations in which children become victimized so they can be told what to do in case of sexually inappropriate advance from someone, the findings of the present study would contribute to a better understanding of factors that facilitate or interfere with the adaptive functioning and recovery of the victims.

This study focused on obtaining simple straightforward information of specific details of abuse incidents that included age of victim at time of abuse, relation to perpetrator, location of incident, circumstances, the reaction (reporting to family or anyone else, emotional response), response of family in case of reporting and seeking help or treatment and usefulness of treatment.

1. The present research was conducted in accordance with APA ethical guidelines and it was approved by the Board of Studies in Applied Psychology, University of the Punjab. Prior to taking part all participants were fully informed as to the purposes of this study.

\section{STUDY I}

\section{Method}

This research was designed as a qualitative study and Interviews were used for data collection.

Interview facilitates the researcher's deeper understanding of experiences of people that is not possible through mere questionnaires. Understanding the experiences of participants requires attentive listening to their voices as they tell their own stories. It helps the researcher to interpret and better understand the complex reality of lived experiences.

\section{Sample}

For this study, sample consist of 5 females who had history any kind of sexual abuse. Sample was selected through snow ball sampling because it was a specific criteria. Researcher was approached the first participant with the help of her friend who knew the lady she had history of

(c) The International Journal of Indian Psychology, ISSN 2348-5396 (e)| ISSN: 2349-3429 (p) | 193 
sexual abuse researcher took her number and approach her for taking information regarding her experiences. $1^{\text {st }}$ participant referred the researcher to 2 more clients so in this way researcher took the data of 3 participants remaining 2 participants information took from Dar ul Aman $3^{\text {rd }}$ participant told the researcher that there are the females having domestic violence researcher took lots of interviews from there but 2 was there who fulfill the criteria of this study.

All participants' belonged to different families and backgrounds. Table 2.1 shows the age, education, marital status and occupation of the participants at the time of interview.

\section{Procedure}

First of all process of interview protocol was designed for the interviews. Female participants were contacted and approached through personal contacts. Informed consent was obtained after describing purpose of study, ensuring anonymity and safety of information. Beginning with an orientation phase that was designed to explain the nature and purpose of the study, participants were ensured that personal information i.e., name and location, would be kept confidential. After getting their consent the formal interview was started. The interview took 40-60 minutes. The interview began with context questions that provided the understanding about context of the incident of sexual abuse. The researcher shared that many women go through this as she has observed and heard from her peers and it would be useful to have their story as it would help many children in similar situation. This open ended question was followed by probing questions when necessary to explore the information. After getting detailed information, the researcher expressed thanks to the participants. Each interview was transcribed and analyzed using content analysis.

\section{Findings}

(Table 2).

Various aspects of sexual abuse come out in the findings (Table 2) Incident happen in home have high frequency then outside. Three out of five participants were abused by their close relatives [uncles (mamo)] and 2 were abused by family friends. Most common form was kissing, touching body parts and showing pornography. Among 4 of 5 participants reported their responses about sexual abuse the reaction of the one participant's family was not supportive they didn't trust her one of them parent was scold her and asked to keep the mouth shut and 2 of them was supportive and help them to overcome from trauma. The emotional effects reported are: sad mood and feeling unhappy, feeling isolated, worthless and crying episode. Physical effects experienced were palpitation, trembling and increasing heart beat immediately after abuse. Some victims of sexual abuse felt sexual repulsion and have difficulty accepting closeness to men. 3 out of 5 participants sought counseling but 1 of 3 participants took counseling after very long time. Two women reported taking sleeping pills for the quality of sleep. 
Table 4 represents themes of feelings at time of incident is common in participants. It is observed that fear and low self-esteem almost have same in all participants. It is also observed that victims of this incident have guilt and shame from the situation. The findings also represents common symptoms of psychological reactions of participants. It is resulted the depression is on high peak after long time of incident. Some participants reported anxiety symptoms and some have sexual repulsion and have to face difficulty to make relation with their husband. It is also observed that the symptoms of phobia are also faced by the participants.

\section{STUDY II}

\section{Method}

The aim of the study II was to explore the depiction of sexual abuse stories taken from the internet. Three anonymous stories were taken from the website of hero project and escaping Hades. The stories are selected on the basis of inclusion criterion i.e., childhood sexual abuse. These stories illustrated psychological and emotional disturbances of the victims and were analyzed to understand what effects and associated variables of sexual abuse are reported in these anonymous stories.

These stories are supporting our findings. In (Figure1) similar themes found in the three stories and live experience of sexual abuse females. Similarity in the Role of perpetrator in all the Three Stories sexually abused females (Figure 2). The findings revealed in (Figure 3) there are similarity in the personality of victims in All Three Stories. (Figure 4) describes similarity in the role of mother in three stories abused females. Mother Child relationship of $3^{\text {rd }}$ story describe in (Figure 5).

\section{Summary of Findings}

The research attempted to gain an understanding the perceive problems of the experiences of childhood sexual abuse. The results highlighted many problems that are faced by the sexually abused people. The face psychological problems like anxiety, depression, phobia, sexual repulsion, adjustment problems and issues related marriage and education.

The themes that emerged from the analysis of experiences are similar to those of interview and in content analysis. The similar themes are psychological problems faced by the participants like symptoms of depression, anxiety, sexual repulsion, phobia, adjustment problems, less bond between parent and child, marriage issues and education effected by the situation.

\section{Discussion}

This study sought to gain some basic information on incidents and experiences of childhood sexual abuse among adult women. The findings suggest that they face psychological problems like low self-esteem, anxiety, depression, phobia, sexual repulsion, shame and guilt, adjustment problems and issues related marriage and education. As a participant reported: 
"I was feeling worthless I thought there is nothing for me. Most of the time I feel sad and unhappy and wanted to be isolated".

A participant who had experience difficulties of interpersonal relationship (sexual repulsion) reported as:

"My relationships with my husband are not enough satisfactory we are not close enough... I mean....I always reluctant to share my feelings with him and sometime I refuse to close with him avoid to make relation for a long time”.

Similarly, Mullen (1994) examine effects of sexual abuse on social interpersonal and sexual function in adult life. He found significant association between child sexual abuse and interpersonal relationships which increased sexual problems and a disruption in intimate relationship by difficulties with trust and perceived their partner as uncaring person.. Moreover, those who reporting childhood sexual abuse are more likely to suffer social interpersonal sexual difficulties in adult life (Mullen, 1994).

Present findings suggested that perpetrators were mostly abuse by their close relatives. A participant reported as:

"I was molested in the car by my maternal uncle. My uncle had taken my family shopping and had dropped them at a store while he waited in the parking lot. I was with my uncle. My uncle asked me to sit on the front seat. He first started touching on my chest, then put his hands inside the shirt, and then into the trousers. I was too much scared".

Another participant reported that:

"I was molested in my home by maternal uncle. My uncle sometimes asked me to sit in his lap. One day he sat in his lap trying to kiss me in a wrong way. I was feeling ashamed and being forced. Tried to run away but he held me tightly"

Csobra (2006) supported the findings. He reported that the $44 \%$ perpetrator was the victim's father, $40 \%$ was step- father. It can be concluded that the majority of the abuser were from their families, may be they can easily approach them and have no fear to be get disclosed.

The present study also found that parents' response is not always helpful or supportive. Only 3 women shared their incident with mother and the response was discouraging: As a participant expressed her views regarding family:

"I told my mother about this incident. But my mother did not believe me and slapped me.

Another participant reported:

"I tried to tell my mother but she scolded me and asked me never to say such words against my uncle”.

(C) The International Journal of Indian Psychology, ISSN 2348-5396 (e) | ISSN: 2349-3429 (p) | 196 


\section{Unprotected In an Islamic Country; Experiences of Childhood Sexual Abuse among Pakistani Women}

Mary's story from web site also consistent with finding of present study:

"I told my mother the first time but she did not trust me. I was being abused for a long time with different people and then I did not tell my mother because she did not trust me”.

In present study after the experience of abuse all victims report being disturbed. However only 2 went for treatment in adulthood and both report feeling relaxed and being able to relieve the haunting and traumatic memory. However the counseling was sought in adulthood not in childhood and this may be too late. One participant used drugs for relaxation.

"I was too much disturbed, unhappy, sad and also feeling worthless when my mother did not trust me. I took sleeping pills for relaxation.

It can be concluded that majority was abused in their homes and by their relatives mostly uncle and the anonymous stories also showed that the victims were abused by their relatives and inside their homes. The kind of abuse (kissing, touching genital organs, sexual intercourse) was similar in the participants and the in anonymous stories. The majority reported experiences about the incident was not supportive which leads the victim towards psychological problems such as: sad mood, unhappy, feeling of worthless, self-blame, shame and guilt. It can be concluded that victims may took drugs after the incident but those, who were taking counseling may have coped in better way.

It is limited in scope due to only female participants but the purpose of study is accomplished. Further studies should include adult males as sexual abuse among boys is as common. However, the present findings have important implication for victims of sexual abuse, extended family members and social community. Children spend more time with their family, parents, siblings and relatives as home is always considered a protected place. When they experience sexual abuse at their homes by their relatives, it breaks their trust and make them feel insecure which have negatively affect their quality of life, relationship and their skills. Hence it is important to systematically plan for their protection. Through this study we are able to make such a plan and that is the contribution of this study.

It is suggested that parents need to listen their children carefully, take them seriously, and investigate, not to trust male relatives, not to leave them alone, look for signs of distress among children, and closely watch their male teachers, servants, uncles, friends and even Quran teachers. Do not leave their children alone with any adult except parents (even fathers are not safe). Moreover, parents need to teach their children what they have to do if someone touches them against their will.

Parents should first get awareness about this matter by themselves and then should teach their children about it. In this case parents are further suggested not to get only surface knowledge about it but a bit of extensive knowledge, for instance almost everyone knows that sexual abuse 
is a crime but a very few, even well educated people, knows what kind of apparently little acts can fall in the ambit of sexual abuse. Moreover, parents should be open to their children, so the children can tell their parents in case of sexual abuse and parents should not castigate their children in such cases as the trend of hostility towards the victims of sexual abuse by their parents is quite prevalent in our society. In case of abuse is confirmed, first of all parents should report it to concerned authorities for the want of proper legal action against the offender(s) and for the victims, parents should get him/her consulted by some competent therapist even if they find no apparent harm to their children. Unfortunately, like the scarcity of specialist therapists in many other fields, we do not have enough trained therapists to cure the repercussions of sexual abuse. Even the therapists like general practitioners can only be found in big cities. In far flung cities and especially in the villages, where these therapists are required more than in the big cities, we do not have them. The partial liabilities falls on the universities and the clinical centers along with the government that universities and clinical centers should start specialized courses of child abuse and make the training of therapists and counselors rigorous in it.

\section{Acknowledgments}

The author appreciates all those who participated in the study and helped to facilitate the research process.

\section{Conflict of Interests}

The author declared no conflict of interests.

\section{REFERENCES}

Ahmad, M. (2012). Psychological functioning and coping strategies among the survivors of childhood sexual abuse. Unpublished Institute of Clinical Psychology University of the Punjab.

Alexander, P. C. \&Luper, S. L. (1987) Family characteristics and long term consequences associated with sexual abuse. Archives of Sexual Behavior, 16, 235-245.

Ali, A. (2005). Adult psychological problems as a result of abused childhood. Unpublished Manuscript Institute of Clinical Psychology, University of Karachi, Retrieved February 22, 2014.

Andrews, G., Corry, J., Slade, T., et al (2002) Comparative Risk Assessment: Child Sexual Abuse (final report). Sydney: St Vincent's Hospital, Clinical Research Unit for Anxiety and Depression (CRUfAD).

Bifulco.A,G. W. Brown and Z. Adler (1991). Early child abuse and clinical depression in adults. The British Journal of Psychiatry 159, 115-122.

Brier, J (1989). Therapy for adults molested as children: Beyond survival. New York: springer.

Brier, J. \&Runtz M. (1998). Symptomology associated with Childhood Sexual Abuse. Victimized in a non-clinical Adult sample. Child Abuse \& Neglect, 12: 51-59.

Burnam, M. A., Stein, J. A., Golding, J. M., et al (1988) Sexual assault and mental disorders in a community population. Journal of Consulting and Clinical Psychology, 56, 843 -850. 


\section{Unprotected In an Islamic Country; Experiences of Childhood Sexual Abuse among Pakistani Women}

Bwuico, A., Brown,0. W. \& Aimer. Z. (1991). Early sexual abuse and clinical depression in adult life. British Journal of Psychiatry, 159, 115-122

Check, W. (1989). Child Abuse: The Betrayal of Trust (pp.15-18). New York: Chelsa House publishers.

Diagnostic and Statistical Manual of Mental Disorders. American Psychological association. $4^{\text {th }}$ edition.

Fergusson, D. M. \& Mullen, P. E. (1999) Fergusson, D. M. \& Mullen, P. E. (1999) ChildhoodSexual Abuse: An Evidence-Based Perspective Sexual Abuse: An EvidenceBased Perspective.

Fondacaro, K. M., Holt, C., \& Powell, T.A. (1999). Psychological impact of childhood sexual abuse on male inmates: the importance of perception. Child Abuse \& Neglect, 23, 361-369.

Gauthier, L., Stollak, G., Messe,L.(1996). Recall of childhood neglect and physical abuse as differential predictors of current psychological functioning. Child Abuse \& neglect, 20, 549-559.

Hameed.S. (1996).Depression and Psychological adjustment of male and female children of single parents. University of the Punjab.

Jehu, D., (1988). Beyond Sexual Abuse: Therapy with women who were childhood victim. Wiley, Chichester.

Jehu, D. Klassen, C., \&Gazan, M (1986) Cognitive restructuring of distorting beliefs associated with childhood sexual abuse. Journal of Social Work and Human Sexuality, 4, 49-69.

Jonathan. H, Andrew. P, Elizabeth. B, Marie. B, Lynn R, Rachel. D \&Kathe.H (2001). Child Sexual abuse, poor parental care and adult depression: evidence for different mechanism. The British Journal of Psychiatry179, 104-109.

Kemp, R., \&Kempe, H. (1997).Child Abuse. The Developing Child. USA: Harvard University Press.

Lindert J, V. Ehrenstein O.S, Grashow R, Gal G, Braehler E, Weisskopf. M.G.(2013). Sexual and Physical Abuse in childhood is associated with depression and anxiety over the life course: systematic review and meta-analysis. Department of Public Health, Protestant University of Ludwigsburg.

Marrow.S.L. smith, M.L. (1995).Construction of Survival and Coping by Women who have survived Childhood Sexual Abuse.Journal of Counseling Psychology, 42: 24-33.

Mullen. P. G.. Martin. J. L.. Anderson, J. L.(1994). The effect of child sex abuse on social interpersonal and sexual function In adult life. British journa1 of Psychiatry 165 35-47.

Sanderson, C. (1990). Theoretical Approaches to Childhood Sexual Abuse, (pp. 22-42). London: Jessica Kingsley Publishers.

Watkins, B. \&Bentovim, A. (1992) Watkins, B. \&Bentovim, A. (1992). The sexual abuse of male children and adolescents: a review of current of male children and adolescents: a review of current research. Research. Journal of Child Psychology and Psychiatry and Allied Disciplines, 33, 197-248. , 197-248.

Wenar.C. (1994).Developmental Psychopathology: from infancy through adolescence. ( $3^{\text {rd }}$ ed). The Ohio State University.

Yahia, M., \&Tamish.S (2001).The rates of child sexual abuse and its psychological consequences as revealed by a study among Palestinian University students. Child Abuse \& Neglect, 25, 1303-1327.doi./10.1016/S0145-2134 (01)00277-0. 
Table 1 Demographic Characteristics of participants

\begin{tabular}{|l|l|l|l|l|l|}
\hline Participants & $\mathbf{1}$ & $\mathbf{2}$ & $\mathbf{3}$ & $\mathbf{4}$ & $\mathbf{5}$ \\
\hline $\begin{array}{l}\text { Age at time of } \\
\text { abuse }\end{array}$ & 11 & 08 & 10 & 12 & 14 \\
\hline Current age & 25 & 22 & 24 & 23 & 30 \\
\hline Education & Graduation & Matric & Primary & Matric & Matric \\
\hline Occupation & Student & House wife & Stay at home & Stay at home & House wife \\
\hline Marital status & Single & Married & Single & Single & Married \\
\hline
\end{tabular}

Table II Content Analyses

\begin{tabular}{|c|c|c|c|c|c|c|c|c|c|c|}
\hline 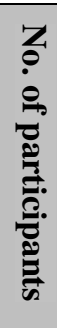 & 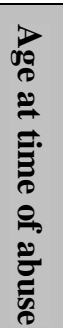 & 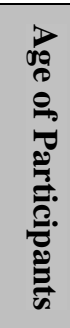 & 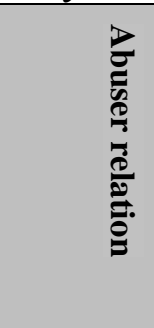 & 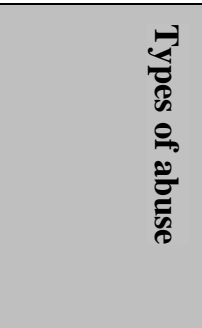 & 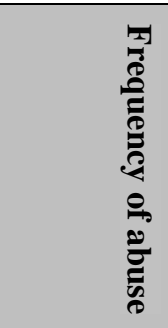 & 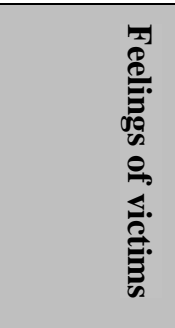 & 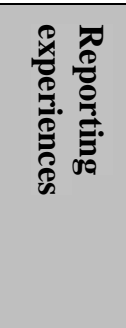 & 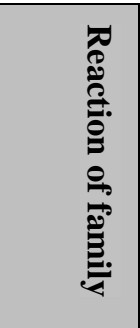 & 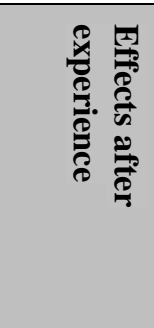 & 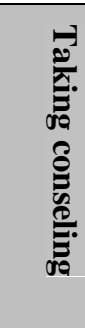 \\
\hline 1 & 11 & 25 & Uncle & Kissing & Sometimes & $\begin{array}{l}\text { Feeling } \\
\text { forceful } \\
\text { attempt }\end{array}$ & Mother & $\begin{array}{l}\text { Don’t } \\
\text { trust } \\
\text { her }\end{array}$ & $\begin{array}{l}\text { Feeling } \\
\text { worthless } \\
\text { no one } \\
\text { care for } \\
\text { her }\end{array}$ & Yes \\
\hline 2 & 08 & 22 & Uncle & $\begin{array}{l}\text { Touching } \\
\text { genitals }\end{array}$ & 1 time & $\begin{array}{l}\text { Fear from } \\
\text { that } \\
\text { person or } \\
\text { sometimes } \\
\text { to all men }\end{array}$ & $\begin{array}{l}\text { Mother } \\
\text { and } \\
\text { sister }\end{array}$ & $\begin{array}{l}\text { Support } \\
\text { her }\end{array}$ & $\begin{array}{l}\text { Sad } \\
\text { mood } \\
\text { and don't } \\
\text { want talk } \\
\text { anyone }\end{array}$ & yes \\
\hline 3 & 10 & 24 & Servant & $\begin{array}{l}\text { Try to touch } \\
\text { her genital, } \\
\text { sexual } \\
\text { intercourse }\end{array}$ & $\begin{array}{l}\text { Many } \\
\text { times }\end{array}$ & $\begin{array}{l}\text { Fear from } \\
\text { home }\end{array}$ & $\begin{array}{l}\text { Did } \\
\text { not tell } \\
\text { anyone }\end{array}$ & & $\begin{array}{l}\text { Feeling } \\
\text { trembling } \\
\text { and high } \\
\text { rate of } \\
\text { hert beat }\end{array}$ & No \\
\hline 4 & 12 & 23 & $\begin{array}{l}\text { Friends } \\
\text { cousin }\end{array}$ & $\begin{array}{l}\text { Show } \\
\text { pornography } \\
\text { to pretend } \\
\text { games on } \\
\text { computer }\end{array}$ & 3 times & $\begin{array}{l}\text { Avoidance } \\
\text { of friends } \\
\text { home }\end{array}$ & Mother & $\begin{array}{l}\text { Scold } \\
\text { her }\end{array}$ & $\begin{array}{l}\text { Think } \\
\text { about the } \\
\text { situation } \\
\text { and } \\
\text { feeling } \\
\text { crying }\end{array}$ & No \\
\hline 5 & 14 & 30 & $\begin{array}{l}\text { Fathers } \\
\text { colleague }\end{array}$ & $\begin{array}{l}\text { Kissing and } \\
\text { trying to } \\
\text { touch her } \\
\text { shoulders }\end{array}$ & 1 time & $\begin{array}{l}\text { Forceful } \\
\text { attempt } \\
\text { and fear to } \\
\text { go in front } \\
\text { men }\end{array}$ & $\begin{array}{l}\text { Tell } \\
\text { her } \\
\text { mother }\end{array}$ & $\begin{array}{l}\text { Support } \\
\text { her }\end{array}$ & $\begin{array}{l}\text { Fear and } \\
\text { cut off } \\
\text { from } \\
\text { everyone } \\
\text { avoid of } \\
\text { making } \\
\text { friends }\end{array}$ & 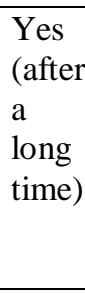 \\
\hline
\end{tabular}

(c) The International Journal of Indian Psychology, ISSN 2348-5396 (e)| ISSN: 2349-3429 (p) | 200 
Unprotected In an Islamic Country; Experiences of Childhood Sexual Abuse among Pakistani Women

Table III Frequency Distribution of various characteristics of abuse

\begin{tabular}{|c|c|c|}
\hline Main Category & Sub Category & Frequency \\
\hline \multirow[t]{3}{*}{ Setting } & Where incident happen & \\
\hline & Home & 4 \\
\hline & Outside & 1 \\
\hline \multirow[t]{3}{*}{ Relationship with perpetrator } & Relative & 3 \\
\hline & Family friend & 1 \\
\hline & Servant & 1 \\
\hline \multirow[t]{4}{*}{ Kind of abuse } & Kissing & 3 \\
\hline & Touching genitals & 2 \\
\hline & Pornography & 1 \\
\hline & Sexual intercourse & 1 \\
\hline \multirow[t]{3}{*}{ Reporting experience } & Supportive & 2 \\
\hline & Non Supportive & 3 \\
\hline & No reporting & \\
\hline \multirow[t]{17}{*}{ Psychological effects } & Depression & \\
\hline & - Sad mood & 4 \\
\hline & - Unhappy & 6 \\
\hline & - Isolation & 3 \\
\hline & - Crying & 2 \\
\hline & - Self-blame & 1 \\
\hline & - Worthless & 4 \\
\hline & Anxiety & \\
\hline & - Palpitation & 2 \\
\hline & - Trembling & 1 \\
\hline & - Increase heart beat & 2 \\
\hline & Sexual repulsion & \\
\hline & - Reluctant to make relation & \\
\hline & With men & 1 \\
\hline & Phobia & \\
\hline & - Fear from men & 3 \\
\hline & - Fear of darkness & 2 \\
\hline Taking treatment & Counseling/no treatment & 3,2 \\
\hline Taking drugs & sleeping pills & 1 \\
\hline
\end{tabular}

(C) The International Journal of Indian Psychology, ISSN 2348-5396 (e)| ISSN: 2349-3429 (p) | 201 
Table IV. Themes depicted if feelings after incident

\begin{tabular}{|c|c|c|}
\hline Main Category & Sub Category & Example \\
\hline Fear & $\begin{array}{l}\text { 1. Felt fearful that a } \\
\text { tragedy could happen } \\
\text { felt vulnerable. } \\
\text { 2. Felt scared about } \\
\text { future. }\end{array}$ & $\begin{array}{l}\text { Dar lagta tha esa lagta tha } \\
\text { kuch bura honay wala haai. } \\
\text { Ghar sai dar lagna shuru ho } \\
\text { gya khas tor pai tab jab ami } \\
\text { ghar nahi hoti thi }\end{array}$ \\
\hline Shame/Guilt & $\begin{array}{l}\text { 1. Shame towards their } \\
\text { actions. } \\
\text { 2. Felt shame if someone } \\
\text { knows about this. }\end{array}$ & $\begin{array}{l}\text { Muje apnay baray maai ganda } \\
\text { ganda mehsoos hota tha yani } \\
\text { mai lambay arsay tak ihsas e } \\
\text { nidamat ka shikar ho gai thi. }\end{array}$ \\
\hline Low Self-esteem & $\begin{array}{l}\text { 1. Low self-confidence } \\
\text { and not feeling good } \\
\text { about self. }\end{array}$ & $\begin{array}{l}\text { Mai khud k baray mai acha } \\
\text { mehsoos nahi kerti thi muje } \\
\text { lagta tha mai baki logo ki } \\
\text { tarha nahi rahi ho. }\end{array}$ \\
\hline Depression & $\begin{array}{l}\text { 1. People with depressed } \\
\text { mood have some } \\
\text { somatic complaints } \\
\text { (weight loss/gain and } \\
\text { sleep disturbance), } \\
\text { cognitive complaints } \\
\text { (sense of } \\
\text { worthlessness, guilt, } \\
\text { difficulty } \\
\text { concentration) and } \\
\text { behavioral complaints } \\
\text { (psychomotor } \\
\text { agitation, psychomotor } \\
\text { agitation). }\end{array}$ & $\begin{array}{l}\text { Mai udas rehti thi khud ko } \\
\text { bohat akela mehsoos kerti thi. } \\
\text { Esa lagta tha meri kisi ko } \\
\text { zarorat nahi or mai ziada waqt } \\
\text { roti rehti thi or tanhai mai } \\
\text { ziada achi lagti thi. }\end{array}$ \\
\hline Anxiety & $\begin{array}{l}\text { 1. It include excessive } \\
\text { worry and anxiety } \\
\text { about number of } \\
\text { activities or events } \\
\text { difficulty controlling } \\
\text { the worry related } \\
\text { symptoms such as } \\
\text { restlessness, tiring } \\
\text { easily, body tension, } \\
\text { and disturbed sleep. }\end{array}$ & $\begin{array}{l}\text { Har waqt bechaini hoti thi. } \\
\text { Baithay baithay hath pao sai } \\
\text { paseena choot jata or kabhi } \\
\text { kabar dil ki dharkan b taiz ho } \\
\text { jati thi. }\end{array}$ \\
\hline Sexual repulsion & & $\begin{array}{l}\text { Shohar acha nahi lagta tha. } \\
\text { Koi b mard acha nahi lagta } \\
\text { tha. }\end{array}$ \\
\hline Self-blame & & $\begin{array}{l}\text { Muje esa lagta tha aj mai jin } \\
\text { halat mai ho apni hi waja saai } \\
\text { ho. }\end{array}$ \\
\hline
\end{tabular}

(c) The International Journal of Indian Psychology, ISSN 2348-5396 (e)| ISSN: 2349-3429 (p) | 202 
Unprotected In an Islamic Country; Experiences of Childhood Sexual Abuse among Pakistani Women
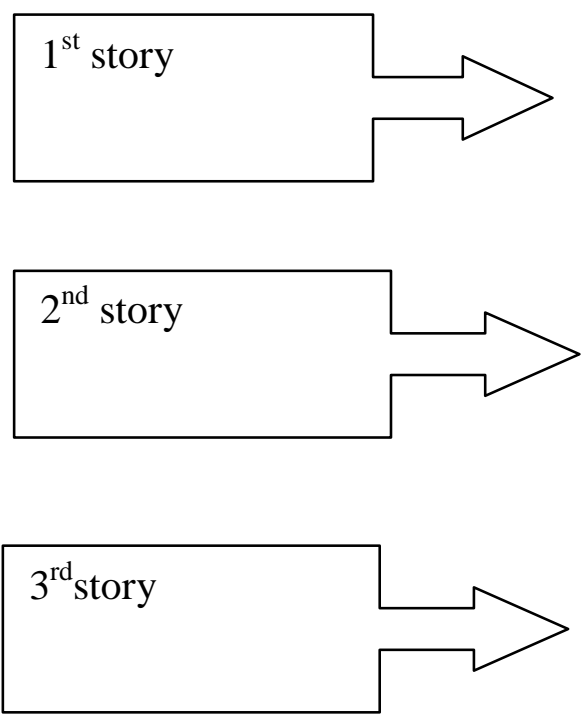

Childhood sexual abuse

Abused by relative

Ineffective mother child relationship

Psychological problems

Figure1.Similar themes found in the three stories.

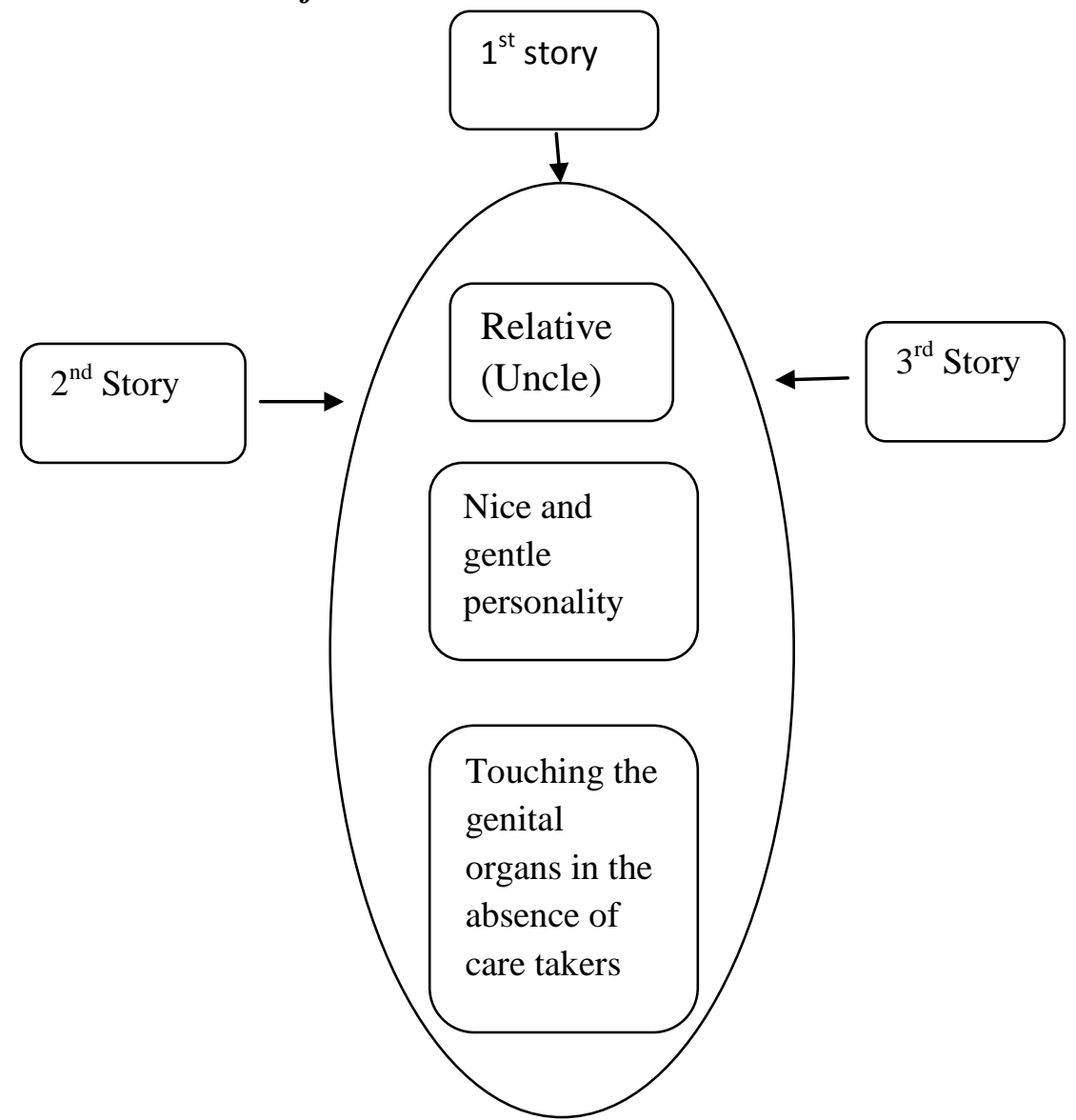

Figure 2.Similarity in the Role of perpetrator in all the Three Stories.

(c) The International Journal of Indian Psychology, ISSN 2348-5396 (e) | ISSN: 2349-3429 (p) | 203 
Unprotected In an Islamic Country; Experiences of Childhood Sexual Abuse among Pakistani Women

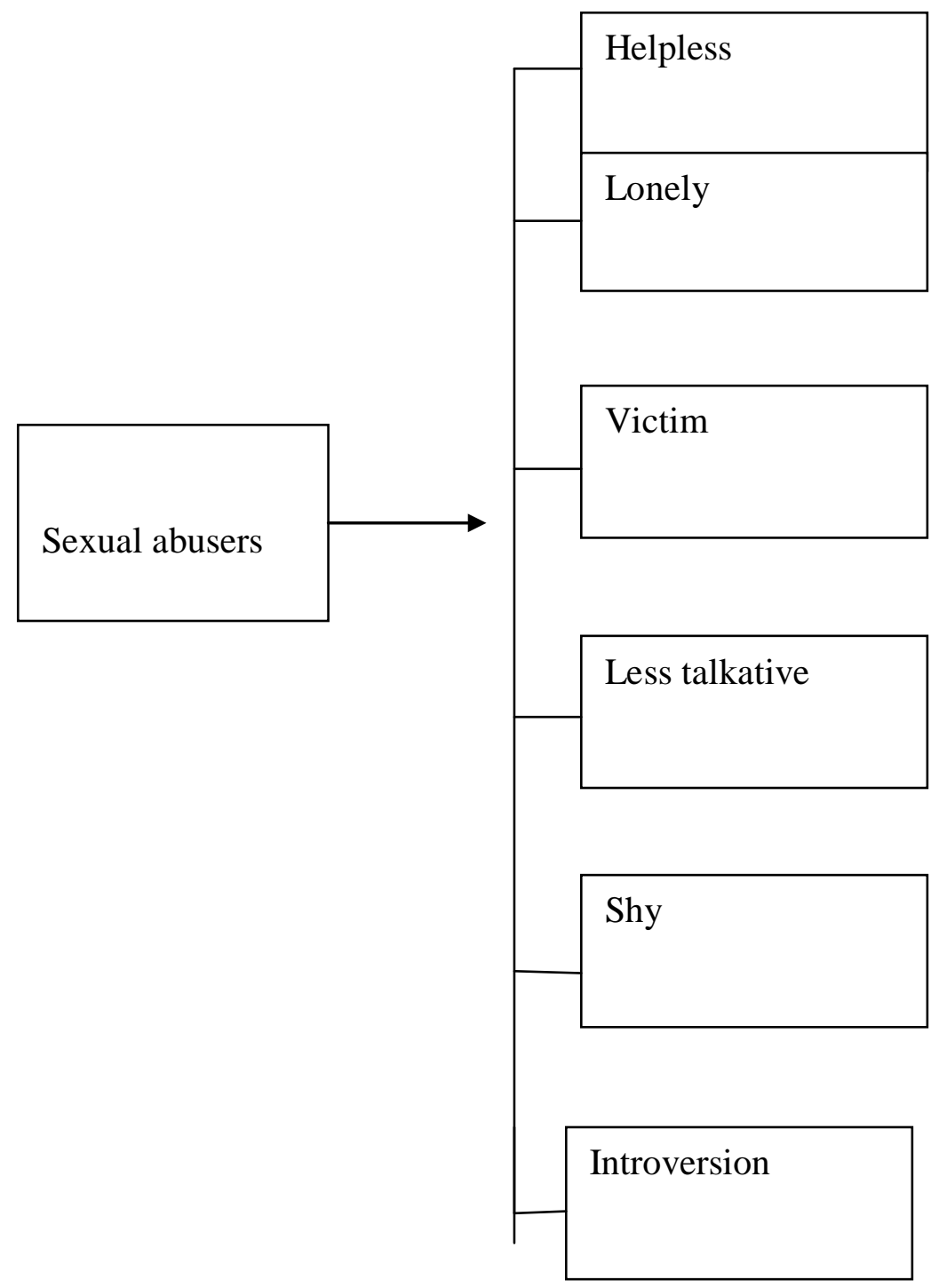

Figure 3. Similarity in the personality of victims in All Three Stories.

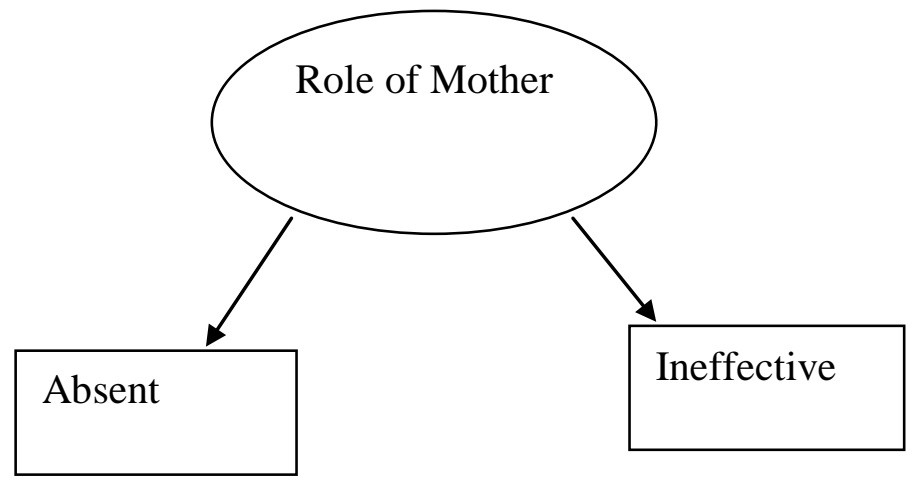

Figure 4. Similarity in the role of mother in three stories.

(c) The International Journal of Indian Psychology, ISSN 2348-5396 (e)| ISSN: 2349-3429 (p) | 204 


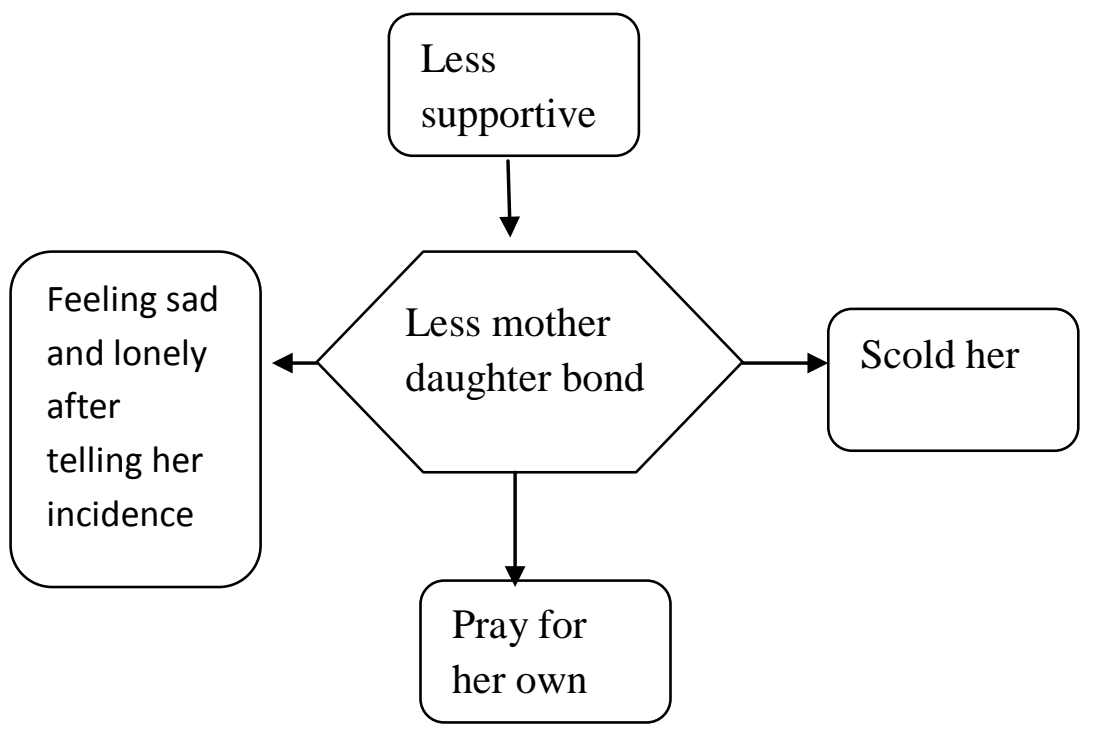

Figure 5. Mother Child relationship of $3^{\text {rd }}$ story.

How to cite this article: A Shahid, N Amjad (2016), Unprotected In an Islamic Country; Experiences of Childhood Sexual Abuse among Pakistani Women, International Journal of Indian Psychology, Volume 3, Issue 4, No. 75, ISSN:2348-5396 (e), ISSN:2349-3429 (p), DIP:18.01.058/20160304, ISBN:978-1-365-50727-4

(c) The International Journal of Indian Psychology, ISSN 2348-5396 (e)| ISSN: 2349-3429 (p) | 205 